Agro-Science Journal of Tropical Agriculture, Food, Environment and Extension Volume 20 Number 3 (July 2021) pp. 53 - 64

ISSN 1119-7455

\title{
UTILIZING URBAN REFUSE WASTES AS SOIL AMENDMENT IN SUB-SAHARAN AFRICA: PROSPECTS AND CHALLENGES IN THE NIGERIAN CONTEXT
}

\author{
*11 Alhassan A.B., ${ }^{1}$ Chiroma A.M., ${ }^{2}$ Kundiri A.M., ${ }^{1}$ Bababe B. and ${ }^{3}$ Tekwa I.J. \\ Department of Soil Science, University of Maiduguri, PMB-1069, Borno State, Nigeria \\ ${ }^{2}$ Office of the Vice Chancellor, Federal University, Wukari, PMB-1020, Taraba State, Nigeria \\ ${ }^{3}$ Department of Soil Science \& Land Resource Management, \\ Federal University, Wukari, PMB-1020, Taraba State, Nigeria \\ *Corresponding author’s email: abbalhassan@gmail.com, abalhassan@unimaid.edu.ng
}

\begin{abstract}
The challenge of effectively managing the huge wastes generated in most Nigerian cities raises serious environmental concerns with environmental pollution and ecological deterioration being the most serious concerns. Most municipal authorities responsible for evacuation of town refuse wastes lack the capacity to effectively manage the huge volumes of wastes generated on daily basis due to a number of reasons prominent of which include population explosion, urbanization, industrialization and economic growth. Application of urban refuse wastes (URW) to crop fields offers means of correcting many of the problems associated with collection and disposal of URW in Nigeria. Utilizing organic solid wastes on agricultural fields is an important way of effectively increasing soil organic carbon sequestration and supplying nutrients for crop plants. Proper sorting and composting of the URW has been shown to not only improve the quality of the wastes as organic amendment, but also help in correcting many of the health and environment related challenges associated with its direct application to agricultural lands. This review presents the results of research findings on utilization of $U R W$ as organic amendment and also highlights the constraints, prospects and the sustainability for utilizing URW as bio-fertilizer. It reveals that the average solid wastes generated in most Nigerian cities have a large fraction of organic materials that could easily be utilized as bio-fertilizer. Suggestions on ways to reduce some of the problems associated with land application of $U R W$ are proffered. Possible ways for improving the quality of URW intended for use as organic amendment are also suggested.
\end{abstract}

Key words: Agriculture, compost, heavy metal, organic wastes, sub-Saharan Africa

\section{INTRODUCTION}

The majority of the soils that occur in Nigeria as elsewhere in the arid and semi-arid West Africa are characteristically sandy (60-94\% sand; $4-31 \%$ silt; $2-11 \%$ clay), low in organic matter $(0.2-1.1 \%)$ and cation exchange capacity $\left(<10 \mathrm{cmol} \mathrm{kg}^{-1}\right)$ and very low in basic cations $\left(<2.5,0.5\right.$ and $0.5 \mathrm{cmol} \mathrm{kg} \mathrm{kg}^{-1}$ $\mathrm{Ca}, \mathrm{Mg}$ and $\mathrm{K}$, respectively) (Fajemisin, 1991). According to Fajemisin (1991), their values are between one-tenth and one-third of the desirable levels for clay, organic matter, cation exchange capacity and the basic cations; whereas the sand content is three to four times the structurally active soils. These soils also have several structural impediments such as very weak fragmentary structure, susceptibility to crust formation and low water retention capabilities (Nicou and Charreau, 1985). Although addition of organic matter can play a vital role in improving some of the properties of these coarse textured soils, such improvements are restricted because very little organic matter is produced on soils extremely deficient in plant nutrients (Pieri and Steiner, 1997). There is, therefore, the need to explore other sources of organic matter with proven potentials for improving soil quality. One such option at the moment would be the recycling of urban refuse wastes (URWs). For smallholder farmers, many of whom have little or no access to conventional manures, the concept of recycling of URW offers a means of ensuring long-term soil fertility without the need for external inputs (Karl et al., 1994; Taddese, 2019).

In many developing countries today, particularly Asian countries, composting of URW is being considered as an alternative to expensive fertilizers. For example, the deep, man-made rice soils of China have been developed in this way over centuries (Karl et al., 1994). Increasing the organic matter content by composting organic wastes permits a better soil structure and thus improves retention and transmission of water, air and nutrients (Madeleine et al., 1990). Studies by ElNadi et al. (1995) in Saudi Arabia revealed that application of chicken manure and town refuse compost to sandy soils resulted in expansion of the soils water retention capacity and increased soil

Please cite as: Alhassan A.B., Chiroma A.M., Kundiri A.M., Bababe B. and Tekwa I.J. (2021). Utilizing urban refuse wastes as soil amendment in sub-Saharan Africa: prospects and challenges in the Nigerian context. Agro-Science, 20 (3), 53-64. DOI: https://dx.doi.org/10.4314/as.v20i3.8 
fertility by virtue of their content of the principal nutrient elements required for plant growth and development. There is, however, enormous potential for utilizing urban refuse and similar waste products that are being generated in the country as bio-fertilizer. Urban or municipal refuse wastes are wastes that constitutes portion of the solid waste stream originating from household, institutions, commercial and service establishments, offices and public facilities (Ghaly and Alkonik, 2010).

Urban and peri-urban settlements are expanding rapidly across large parts of Sub-Saharan Africa often at a rate that exceeds the capacity of countries to supply basic services (Lapworth et al., 2018). In the specific case of Nigeria, cities and towns are currently facing serious environmental problem arising from poor solid waste management (Anyanwu and Adefila, 2014). Indeed, the rate at which wastes are building up in Nigerian urban centres is alarmingly greater than the natural process of converting them into harmless substance (Maton et al., 2016). The continued accumulation wastes in most Nigerian cities are posing serious threat to both human health and environmental quality. This excessive accumulation of wastes can have serious adverse effects on human health mainly through direct and indirect exposure to contaminants e.g., via polluted air or the ingestion of contaminated foods (Cullen, 1995). Despite the magnitude of these wastes generated daily and the possible adverse effects on the environment, no serious attempts have been made in the past either for their effective utilization or safe disposal. There are currently limited evidence-based studies on effective utilization of town refuse wastes generated in urban centres across Nigeria with which to inform long term policy on the development of urban and peri-urban groundwater resources. The need for careful planning of soil and water resources management is particularly vital for sustainable agriculture, which is a condition for economic growth, poverty reduction and environmental conservation (Baiyeri et al., 2020). This paper, therefore, reviewed some research findings demonstrating the use of URWs as soil amendment. The paper also highlights the problems associated with direct (untreated) application of URW on agricultural lands and proffers solutions to overcome such problems.

\section{Composition of Urban Refuse Wastes (URWs) in Some Towns/Cities in Nigeria}

Nigeria, being the most populous country in Africa contributes significantly to solid and liquid wastes generation of diverse sources. The main sources of solid waste in the urban areas of Nigeria are domestic, commercial, industries, streets and markets activities. Table 1 shows waste generation in nine selected urban cities in Nigeria. As shown in this table, the estimated daily rate of solid waste generation in Nigeria ranges from $0.44-0.66$ with a mean value of $0.55 \mathrm{~kg}^{-1}$ capita/day. These findings compare well with the range of values $(0.554-$ 1.374 with a mean value of $0.804 \mathrm{~kg}^{-1}$ capita/day) reported for Kinondoni municipality, a fastest growing municipality in Dar es Salaam region, Tanzania. The wide disparity in the results represents the differences in income levels between the eight wards surveyed, where the ward with the least and the highest levels were categorized as medium income and highest income areas, respectively, (Mombo and Bigirwa, 2017). Solid wastes generation in Sub Saharan Africa is ca. 62 million tonnes per year and spans a wide range from 0.09 to $3.0 \mathrm{~kg}$ per person per day with an average of $0.65 \mathrm{~kg}^{-1}$ capita/day (Hoornweg et al., 2014). The reuse of these large amounts of municipal refuse wastes for agricultural purposes will, besides helping to address some of the environmental and public health problems associated with them, improve soil properties and crop yields (Hossain et al., 2017).

It has long been acknowledged that high-density, large amount of organic content, small sized particles and large amount of dust and dirt often characterized wastes generated in developing countries (Anyanwu and Adefila, 2014). In many African cities, organic material forms $50-90 \%$ of urban refuse and the organic fraction includes raw kitchen waste generated in the preparation and consumption of food (food leftovers), rotten fruit, vegetables, leaves, crop residues, animal excreta and bones (Asomani-Boateng and Murray, 1999). Chemical analysis of municipal solid waste from nine Nigerian cities indicates that organic matter fraction averaged $49.8 \%$ of the total volume of waste generated (Ogwueleka, 2009). The combined proportions of plastic, glass, metal and other wastes averaged less than $30 \%$ of the total volume of wastes generated in these cities (Table 2). The organic fractions in the wastes generated from cities of Ibadan and Abuja averaged $76 \%$ and $58.5 \%$, respectively, compared to cities like Maiduguri and Onitsha that generates about 25.8\% and $30.7 \%$, respectively. Earlier survey conducted in fifteen capital cities in Nigeria showed that between 65 and $75 \%$ of the refuse generated are organic in character and are highly compostable (Federal Ministry of Housing and Environment, 1982). The high percentage of organic waste may be attributed to the consumption of unprocessed food as compared to processed food consumed in more developed countries (Oyelola and Babatunde, 2008). The study by Cristina (2013) also showed that about $57.5 \%$ of the residential solid waste generated in eight Nigerian cities was organic in character. The overview of published literature on municipal solid waste composition in many cities in Nigeria and sub-Saharan Africa showed that compostable materials constituted majority of the waste streams (Ajadi and Tunde, 2010; Harir et al., 2015). 
Table 1: Waste generation in some urban cities in Nigeria and the waste management agencies ${ }^{\dagger}$

\begin{tabular}{|c|c|c|c|c|}
\hline City & Agency & Tonnage month ${ }^{-1}$ & Density $\left(\mathrm{kg} \mathrm{m}^{-3}\right)$ & kg capita ${ }^{-1}$ day $^{-1}$ \\
\hline Lagos & Lagos State Management Authority & 255,556 & 294 & 0.63 \\
\hline Kano & Kano State Environmental Protection Agency & 156,676 & 290 & 0.56 \\
\hline Ibadan & Oyo State Environmental Protection Commission & 135,391 & 330 & 0.51 \\
\hline Kaduna & Kaduna State Environmental Protection Agency & 114,443 & 320 & 0.58 \\
\hline Port Harcourt & Rivers State Environmental Agency & 119,825 & 340 & 0.60 \\
\hline Makurdi & Urban Development Board & 24,242 & 300 & 0.48 \\
\hline Onitcha & Anambra State Environmental Protection Agency & 84,137 & 310 & 0.53 \\
\hline Nsukka & Enugu State Environmental Protection Agency & 12,000 & 370 & 0.44 \\
\hline Abuja & FCT Environmental Protection Agency & 14,785 & 280 & 0.66 \\
\hline
\end{tabular}

${ }^{\dagger}$ Adapted from Maton et al. (2016)

Table 2: Municipal solid waste composition in Nigerian cities $\left(\% \mathrm{~kg}^{-1}\right)^{\dagger}$

\begin{tabular}{|c|c|c|c|c|c|c|c|}
\hline Location & *Organic wastes & *Paper & Plastic & Glass & Metal & Textile and leather & Inert and others \\
\hline Makurdi & 52.20 & 12.30 & 8.20 & 3.60 & 7.10 & 2.50 & 14.00 \\
\hline Abuja & 58.50 & 8.00 & 11.30 & 4.80 & 3.10 & $* *$ & 0.20 \\
\hline Maiduguri & 25.80 & 7.50 & 18.10 & 4.30 & 9.10 & 3.90 & 31.30 \\
\hline Kano & 43.00 & 17.00 & 4.00 & 2.00 & 5.00 & 7.00 & 22.00 \\
\hline Onitcha & 30.70 & 23.10 & 9.20 & 9.20 & 6.20 & 6.20 & 15.40 \\
\hline Nsukka & 56.00 & 13.80 & 8.40 & 2.50 & 6.80 & 3.10 & 9.40 \\
\hline Ibadan & 76.00 & 6.60 & 4.00 & 0.60 & 2.50 & 1.40 & 8.90 \\
\hline Lagos & 56.00 & 14.00 & 4.00 & 3.00 & 4.00 & $* *$ & 19.00 \\
\hline Mean & 49.78 & 12.80 & 8.40 & 3.80 & 5.50 & 3.00 & 15.00 \\
\hline
\end{tabular}

${ }^{\dagger}$ Adapted from Ogwueleka (2009), * represents compostable waste fractions, ** represents lack of available data.

\section{Prospects for Utilizing Urban Refuse Wastes (URWs) in Nigeria}

The use of organic wastes in agriculture plays a great role in recycling essential plant nutrients, sustaining soil security as well as protecting the environment from hazards (Hossain et al., 2017). In general, organic materials irrespective of source modify soil properties and boost the soil nutrient content (Adubasim et al., 2018; Stevens et al., 2018). Considering the high organic content of the refuse generated in the country each year, its exploitation for soil amendment could be one important way of tackling the problems associated with refuse collection and disposal in Nigeria. The recycling of wastes in environmentally desirable ways will continue to be one of the society's biggest challenges into the $21^{\text {st }}$ century (Chong, 2001). A growing number of African countries have for long recognized the importance of utilizing various types of organic materials including URW to maintain and improve the productivity of agricultural soils. For example, the practice of utilizing taki (compost from manure, household wastes, street sweepings and ash) as fertilizing material by peri-urban farmers in Kano, has been going on for centuries (Lewcock, 1995). It is estimated that, $25 \%$ of farmer's fertilizer needs in Kano were met by recycling organic solid waste in urban farming (Mortimore, 1972). In many Nigerian towns and cities, abandoned waste dump sites are increasingly being utilized as fertile ground for cultivation of different varieties of crops (Amhakhian et al., 2003; Amusan et al., 2005).

Many of the studies conducted in Nigeria and other developing countries identified the potentials in composting organic waste as a sustainable waste management option (Harir et al., 2015; Akintola et al., 2019; Baiyeri et al., 2020). These studies recognized composting as a viable option for achieving sustainable waste management in developing countries. The review by Akintola et al. (2019) revealed that transforming organic wastes to high quality organic fertilizers will besides helping to transform and stabilize organic materials into stable and usable products, also remove offensive odours, kill weed seeds and pathogenic organisms from the untreated wastes. Similarly, Harir et al. (2015) in a review of solid wastes composting in developing countries concluded that one viable option for achieving sustainable waste management in developing countries is to explore the recovery potentials of organic waste material and papers for composting after carefully sorting out its content of plastic, metals, textiles and other inert materials. This, according to the authors, will largely reduce the ultimate quantities of solid waste for disposal and lower the operating costs.

The beneficial role of urban organic wastes in improving soil properties related to agricultural production had been demonstrated in several studies. A general amelioration of soil structure, porosity and hydraulic properties has been demonstrated (Khaleel et al., 1981; Felton, 1995). Organic wastes not only influence soil properties, but also play a great role in the growth and development of plants and thus improve agricultural productivity. A confirmation of this assertion can be found from the study by Hossain et al. (2017) who reported that application of compost manure to agricultural soils has been shown to improve soil physical and chemical properties, increase soil biological activity, and sustain soil health. Papafilippaki et al. (2015) also reported that addition of URW compost stimulated the growth and yield of spiny chicory and increased bioavailability of trace elements $(\mathrm{Cu}, \mathrm{Zn}, \mathrm{Fe}, \mathrm{Mn}, \mathrm{Cr}, \mathrm{Ni}, \mathrm{Pb}, \mathrm{Cd})$ in 
soils. Under a greenhouse condition, Ouni et al. (2014) also found a similar trend of results with the addition of URW compost to a barley crop. This amendment reportedly increased not only number of leaves per plant and root length but also increased shoot biomass yield by up to $47 \%$. Organic wastes such as URW are also good sources of plant nutrients and influence chemical properties of soil. Scotti et al. (2016) found that after only one year of study, soil treated with URW and manure had 60 and $40 \%$ higher total nitrogen, respectively, compared to the untreated soil. Other studies also showed that the addition of URW compost in soils increased $\mathrm{N}, \mathrm{P}$, and $\mathrm{K}$ contents from 1.70 to 1.76 , 6.20 to 7.30 , and 0.11 to $0.13 \mathrm{~g} \mathrm{~kg}^{-1}$, respectively after a two-year application of URW compost in wetland rice field (Bhattacharyya et al., 2003).

There is also ample evidence in literature that soils at the URW dump sides had improved soil structural condition than the soils at the adjoining non-dump sites. Refuse dump sites had been shown to have $9-13 \%$ lower bulk density in their first and second horizons compared to adjacent non-dump sites (Taddese, 2019). The differences in bulk density between the dump and non-dump sites was attributed to the presence of organic and inorganic materials in the municipal wastes helping to increase the soil matrix thereby reducing bulk density. Incorporation of chicken manure and municipal refuse in sandy soils had also been shown to improve soil properties such as total porosity, water holding capacity, saturation percentage, and mean-weight diameter (Abdel Magid et al., 1994). Increases in aggregate stability due to URW management had been demonstrated in several studies (Khaleel et al., 1981; Bazzoffi et al., 1998; Ros et al., 2001). The increased soil aggregation resulting from the addition of URWs has been shown to drastically reduce runoff and soil loss (Bazzoffi et al., 1998; Ros et al., 2001). Onwudiwe et al. (2014) studied the effects of composted municipal solid waste on the physical properties of a sandy loam soil in South East Nigeria and found that application of the compost at rates ranging from 1 to $2 \mathrm{t} \mathrm{ha}^{-1}$ resulted in modest but non-significant improvement in soil aggregate stability, bulk density, porosity and saturated hydraulic conductivity. These authors attributed the lack of significant treatment effect to the low rate of organic wastes applied and the duration of application. The comparative study by Njoku (2015) revealed that soil bulk density in non-dump site was higher compared to that recorded in municipal, rice mill and timber dump sites by 32,12 and $21 \%$, respectively.

The study by Ros et al. (2001) also demonstrated the importance of urban organic wastes in the control of soil loss and water runoff in a semi-arid Mediterranean soil. These authors found that single addition of three different types of urban organic waste at the rate of 250-300 $\mathrm{t} \mathrm{ha}^{-1}$ resulted in a significant reduction in runoff and soil losses due to increased water holding capacity of the amended soil (43\% urban organic waste, $47 \%$ urban refuse compost, and $24 \%$ sewage sludge). According to the authors, these positive changes slowed down the flow of water and increased the possibility of the runoff water being absorbed by the soil. Comparing the three types of urban organic wastes tested, incorporation of the stabilized organic compost was found to be the most effective treatment, reducing soil loss by $93.8 \%$ and runoff by $54.2 \%$. This was attributed to the greater degree of soil aggregation $(50 \%>$ control plot $33 \%)$ and to the protective effect of the plant cover against raindrop impact. In a similar study, Bazzoffi et al. (1998) evaluated the effects of urban refuse compost on runoff and sediment losses from a bare and cropped field over a period of three years in central Italy. The results show that the addition of urban refuse compost decreased runoff in all the three-year study period with the differences being significant in the second and third years. This was attributed to the improvement in porosity and aggregate stability of the soil, which in turn increased water infiltration and consequently reduced runoff. Total soil erosion during the growing seasons was also significantly reduced by the applied urban reused compost in the first and third years of the study.

The value of different URWs as organic fertilizers has also been demonstrated in some studies (Murillo et al., 1995; Bababe and Kwari, 1999). Investigating the possibility of utilizing soils from dump sites in Owerri, South East for agriculture, Ubuoh et al. (2012) found that levels of organic carbon, nitrogen, $\mathrm{Ca}, \mathrm{Mg}, \mathrm{K}, \mathrm{Na}$, exchangeable base, base saturation and cation exchangeable capacity were all found to be higher in the upper horizon (between 0.15 and $15-30 \mathrm{~cm}$ ) of the soil in the three dump sites compared to those of the controls, but that there was no consistent variation in the total phosphorus content of the soil in the three sites and their controls (Table 3). Similarly, the study by Bababe and Kwari (1999) revealed that application of municipal refuse waste at the rate of $7.5 \mathrm{t} \mathrm{ha}^{-1}$ significantly improved the fertility of a sandy loam soil in Northeastern Nigeria.

\section{Challenges Associated with Management of Urban Refuse Wastes (URWs) in Nigeria}

In Nigeria, the handling and disposal of URWs that are continuously generated in many urban centers constitute a major problem to both public health and the environment. Only in a few cases that the municipal wastes mostly garbage and wastes from the food processing plants are incinerated or landfilled (Amusan et al., 2005). Presently, management of URWs constitute huge financial burden to the municipal authorities charged with the responsibility of evacuating them. In most African countries, the conventional approach of URW management based 
on collection and disposal has failed to provide efficient and effective services to all urban residents (Asomani-Boateng and Haight, 1999; Maton et al., 2016). Onibokun (1989) observed that municipal authorities were able to collect only $35 \%$ of household waste in Ibadan, and 33\% in Kaduna. The findings of recent survey undertaken in selected Nigerian urban cities revealed that the average rate of waste generation is 25 million tonnes per year, at a rate of 0.44-0.66 kg-1 capita/day (Maton et al., 2016). When wastes are mismanaged, sanitary conditions in the urban environment degenerates steadily with its attendant risk to public health. For example, Adedibu and Okekunle (1989) rated Lagos, the most populous city in Africa as dirtiest capital in the world, where in most parts of the city, streets are partially blocked and many compounds are hemmed in by solid waste. The study by Maton et al. (2016) indicated that increased municipal waste management problem experienced in most cities in Nigeria stemmed from such unethical practices of dumping wastes in streams, runways, drainages, open spaces and burning of combustible materials that release smoke and particulate matter in the environment with attendant negative consequences on the lives of flora, fauna and human beings.

In many cities across Nigeria, a sizeable proportion of household wastes often end up in the drainage systems through the uncontrolled disposal of both solid and liquid wastes into open drains and along roads sides (Figure 1). According to Lapworth et al. (2018), poor management of waste disposal systems in many cities of Nigeria is one of the most pressing and unresolved issues that portends negative impacts in terms of groundwater contamination.

Although the value of URW as a fertilizer is well documented, concern has been expressed about the potential ecological and health risks arising from accumulation of heavy metals in the soil profile as well as their entry into the food chain (Pierzynski and Gehl, 2005; Giannakisa et al., 2014). It is well documented that most of the municipal solid wastes being generated in Nigerian urban centres are harmful to the society and the physical environment as some of them are toxic, biologically active, flammable, corrosive, and radioactive or a combination of the factors (Maton et al., 2016). According to Debiase et al. (2016), application of URW to soil led to accumulation of various kinds of harmful components, especially heavy metals in the soil profile as well as their uptake by the plants. In a similar study, Njoku (2015) compared the heavy metal contents of three waste dumpsites and non-dumpsite in Abakaliki, Southeastern Nigeria and found significant differences in $\mathrm{Pb}, \mathrm{Cu}$ and $\mathrm{Cd}$ levels among all the dumpsites. The contents of $\mathrm{Pb}$, $\mathrm{Cu}$ and $\mathrm{Cd}$ were higher in the municipal waste dumpsite relative to the non-dumpsite. The highest values of all the three trace elements were recorded in the rice mill-waste dumpsite (Table 4).

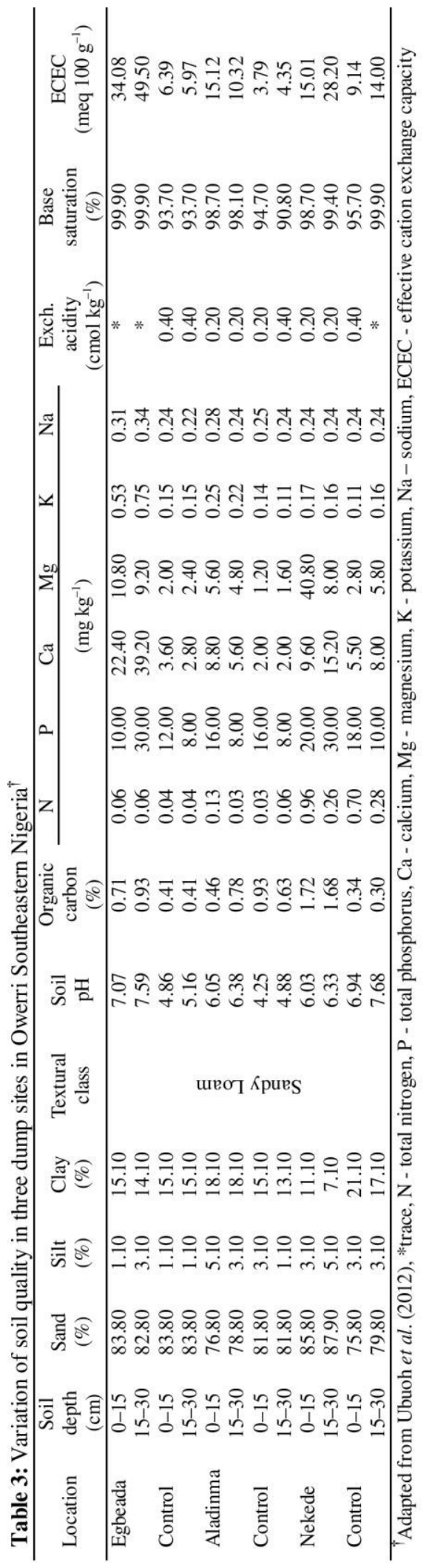

From the results in Table 4, it is clear that waste dumpsite may potentially have toxic effect on plants with respect to $\mathrm{Pb}, \mathrm{Cu}$ and $\mathrm{Cd}$. Similar studies by Bununu et al. (2011) in the Northeastern Nigeria revealed the presence of heavy metals in the soils sampled from several refuse dumpsites (Table 5). 

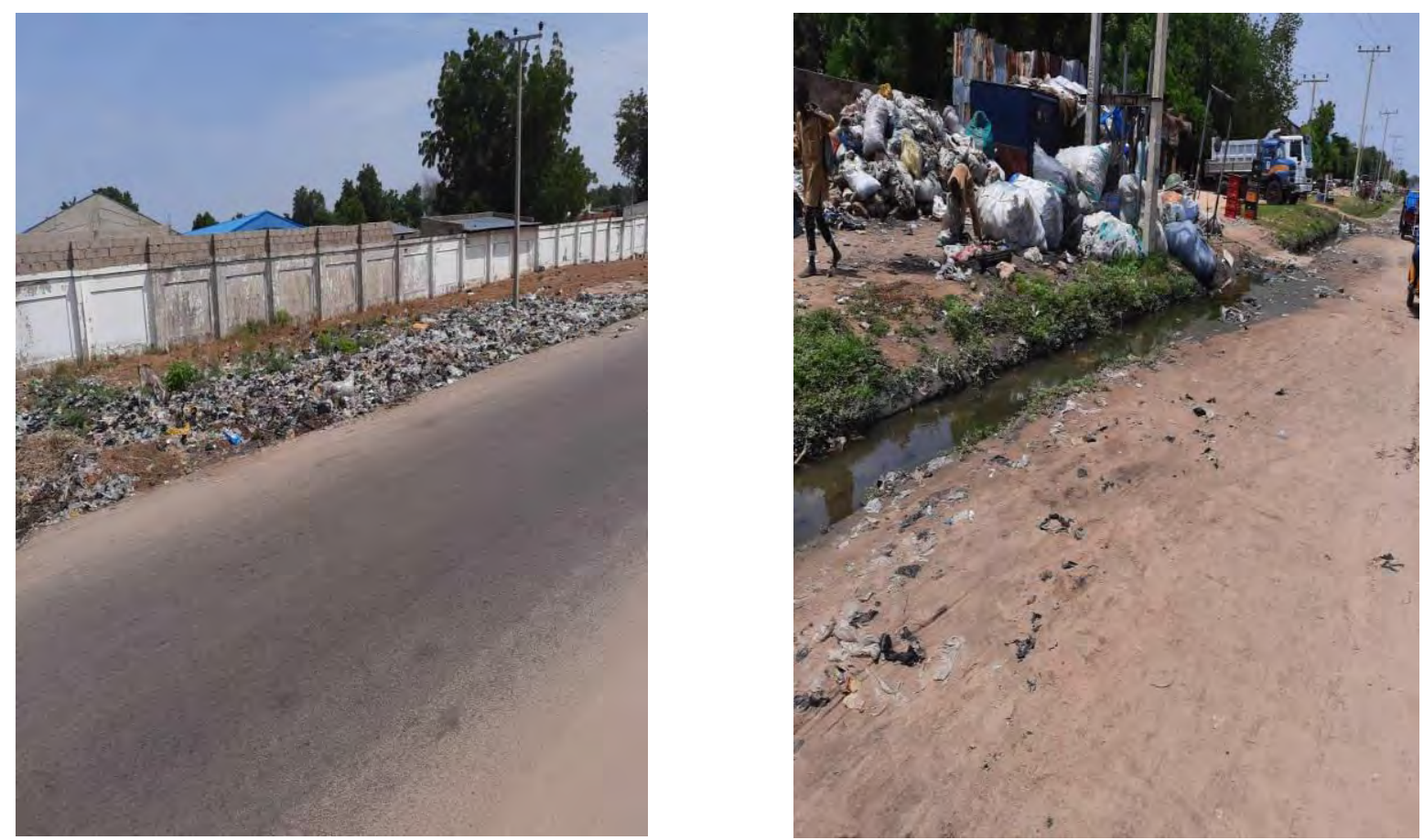

Figure 1: Images of waste dumps on road-sides (left) and blockage of storm drains (right)

The study by Butu and Mshelia (2014) also showed that the municipal solid waste generation in Kano metropolis is very high in non-biodegradable waste such as polythene bags and electronic waste. These materials according to the authors are known to contain high level of metals which are toxic when exposed to above certain limits. These wastes could pose threat to crop production if directly applied to crop fields without prior treatment. These and other similar studies have shown that heavy metals from different organic wastes can accumulate and persist in soils at environmentally hazardous levels. The implication of these results is that crops growing in the dump sites may bioaccumulate considerable quantities of heavy metals in their edible parts. Ingestion of these contaminated plant parts by animals or human beings may cause serious health impairment. The study conducted by Amusan et al. (2005) in Southwestern Nigeria showed that soils from two dump sites; Bode-Osi a rural community and Obafemi Awolowo University, Ile-Ife an urban centre accumulated greater contents of heavy metals compared to that of the control sites. Plants growing on refuse dumpsites were found to accumulate higher contents of heavy metals compared to their counterparts growing in the nearby uncontaminated sites. A recent study by Olayiwola et al. (2017) also revealed a similar trend (Table 6).
These studies, however, cautioned that if the consumption of these metals through plant sources is not carefully regulated, it may lead to accumulation in man with attendant health hazards. Contrary to the reports demonstrating the potential negative impacts of utilizing untreated municipal wastes, the study by Giannakisa et al. (2014) revealed that amending soils with URW compost, even at higher application levels $\left(100 \mathrm{t} \mathrm{ha}^{-1}\right)$ that could be harmful to crop yields or public health did not lead to an increase in the availability of toxic elements (Table 7). The study, however, recommended further studies to confirm the potential risks associated with the long-term addition of URW compost to agricultural soils.

Table 4: Effect of waste on $\mathrm{Pb}, \mathrm{Cu}$ and $\mathrm{Cd}\left(\mathrm{mg} \mathrm{kg}^{-1}\right)^{\dagger}$

\begin{tabular}{lccc}
\hline Dumpsites & $\mathrm{Pb}$ & $\mathrm{Cu}$ & $\mathrm{Cd}$ \\
\hline Non- dumpsite & 4.95 & 2.40 & 0.60 \\
Municipal waste & 14.35 & 4.10 & 0.65 \\
Rice mill waste & 15.15 & 4.30 & 0.80 \\
Timber waste & 12.80 & 3.60 & 0.70 \\
F-LSD $_{(0.05)}$ & 0.10 & 0.30 & 0.48 \\
${ }^{*}$ Acceptable level & $2.00-300.00$ & $2.00-1,500.00$ & $0.01-20$ \\
\hline
\end{tabular}

${ }^{\dagger}$ Adapted from Njoku (2015), *Acceptable level by Alloway (1996)

Table 5: Contents of heavy metals $\left(\mathrm{mg} \mathrm{kg}^{-1}\right)$ in soils of urban refuse dumpsites in Bauchi metropolis ${ }^{\dagger}$

\begin{tabular}{|c|c|c|c|c|c|c|}
\hline Location & $\mathrm{Pb}$ & $\mathrm{Cr}$ & $\mathrm{Cd}$ & As & $\mathrm{Ni}$ & $\mathrm{Zn}$ \\
\hline Wunti & 39.00 & 16.20 & 2.80 & 0.80 & 22.70 & 28.10 \\
\hline Kobi & 15.20 & 5.10 & 1.30 & ND & 5.10 & 11.40 \\
\hline Anguwan Mahauta & 3.70 & 2.80 & 1.90 & ND & 3.70 & 7.60 \\
\hline Jahun & 5.00 & 13.00 & 1.50 & Trace & 10.20 & 10.10 \\
\hline Federal lowcost & 47.20 & 36.20 & 2.40 & 1.30 & 25.30 & 31.50 \\
\hline World bank limit & 150.00 & 50.00 & 3.00 & 10.00 & 50.00 & 300.00 \\
\hline Mean & 22.00 & 14.70 & 2.00 & 1.10 & 13.40 & 17.70 \\
\hline CV $(\%)$ & 90.60 & 90.20 & 31.30 & 27.70 & 75.10 & 62.00 \\
\hline
\end{tabular}

${ }^{\dagger}$ Adapted from Bununu et al. (2011). ND represents not detected. 
Table 6: Concentrations of selected metals in plants $\left(\mathrm{mg} \mathrm{kg}^{-1}\right)^{\dagger}$

\begin{tabular}{|c|c|c|c|c|c|c|c|c|c|}
\hline Location & Sample & As & $\mathrm{Cd}$ & Co & $\mathrm{Cu}$ & $\mathrm{Fe}$ & $\mathrm{Ni}$ & $\mathrm{Pb}$ & $\mathrm{Zn}$ \\
\hline \multirow[t]{4}{*}{ Awotan } & Water leaf (Talinium triangulae) & 0.26 & 0.22 & 0.33 & 0.30 & 0.22 & 0.01 & 0.02 & 0.04 \\
\hline & Barbadoss (Jatropha curcas) & 0.28 & 0.11 & 0.05 & 0.48 & 0.20 & 0.01 & 0.03 & 0.03 \\
\hline & Spinach (Amaranthus cruentus) & 0.36 & 0.21 & 0.32 & 0.28 & 0.24 & 0.02 & 0.07 & 0.03 \\
\hline & Castor plant (Ricinus communis) & 0.17 & 0.12 & 0.28 & 0.36 & 0.23 & 0.03 & 0.02 & 0.04 \\
\hline \multirow[t]{4}{*}{ Ajakanga } & Water leaf (Talinium triangulae) & 0.10 & 0.31 & 0.34 & 0.49 & 0.30 & 0.02 & 0.05 & 0.02 \\
\hline & Barbadoss (Jatropha curcas) & 0.02 & 0.14 & 0.07 & 0.24 & 0.34 & 0.01 & 0.23 & 0.05 \\
\hline & Spinach (Amaranthus cruentus) & 0.08 & 0.43 & 0.36 & 0.33 & 0.23 & 0.02 & 0.03 & 0.04 \\
\hline & Castor plant (Ricinus communis) & 0.03 & 0.27 & 0.26 & 0.47 & 0.28 & 0.03 & 0.20 & 0.03 \\
\hline \multirow{4}{*}{$\begin{array}{l}\text { Farmland } \\
\text { (Control soil) }\end{array}$} & Water leaf (Talinium triangulae) & 0.05 & 0.03 & 0.09 & 0.06 & 0.07 & 0.01 & ND & 0.01 \\
\hline & Barbadoss (Jatropha curcas) & ND & 0.04 & 0.01 & 0.03 & ND & ND & 0.02 & 0.01 \\
\hline & Spinach (Amaranthus cruentus) & 0.03 & 0.02 & 0.05 & 0.07 & 0.02 & 0.02 & ND & 0.06 \\
\hline & Castor plant (Ricinus communis) & ND & ND & 0.02 & 0.01 & ND & 0.04 & 0.01 & ND \\
\hline
\end{tabular}

${ }^{\dagger}$ Adapted from Olayiwola et al. (2017), ND represents not detected.

Table 7: Accumulation of nutrients (\% dry weight) and trace elements in leaves of tomato and lettuce plants and in tomato fruits treated with municipal solid waste compost ${ }^{\dagger}$

\begin{tabular}{|c|c|c|c|c|c|c|c|c|}
\hline \multirow{2}{*}{ Crop } & \multirow{2}{*}{ Treatment } & \multicolumn{7}{|c|}{ Elements (ppm) } \\
\hline & & TKN & $\mathrm{P}$ & $\mathrm{K}$ & $\mathrm{Mg}$ & $\mathrm{Zn}$ & $\mathrm{Cu}$ & $\mathrm{Cr}$ \\
\hline Tomato & $0 \mathrm{t} \mathrm{ha}^{-1}$ & $3.26^{\mathrm{a}}$ & $0.23^{\mathrm{a}}$ & $2.88^{\mathrm{a}}$ & $0.56^{\mathrm{b}}$ & $14.00^{c}$ & $10.00^{\mathrm{b}}$ & 1.00 \\
\hline (leaves) & $50 \mathrm{t} \mathrm{ha}^{-1}$ & $1.94^{\mathrm{c}}$ & $0.10^{\mathrm{c}}$ & $2.86^{\mathrm{a}}$ & $0.86^{\mathrm{a}}$ & $36.00^{\mathrm{a}}$ & $21.00^{\mathrm{a}}$ & 2.00 \\
\hline $01 / 10 / 10$ & 100 tha $^{-1}$ & $2.20^{\mathrm{b}}$ & $0.18^{\mathrm{b}}$ & $3.18^{\mathrm{a}}$ & $0.71^{\mathrm{c}}$ & $21.00^{\mathrm{b}}$ & $18.00^{\mathrm{a}}$ & 1.00 \\
\hline & Signf. & $* *$ & $* *$ & $\mathrm{~ns}$ & $* *$ & $* * *$ & $* *$ & ns \\
\hline Tomato & $0 \mathrm{tha}^{-1}$ & $1.47^{\mathrm{a}}$ & $0.08^{\mathrm{a}}$ & $2.60^{\mathrm{a}}$ & $0.55^{\mathrm{b}}$ & $13.00^{\mathrm{c}}$ & $6.00^{\mathrm{a}}$ & 1.00 \\
\hline (leaves) & $50 \mathrm{tha}^{-1}$ & $1.14^{\mathrm{b}}$ & $0.10^{\mathrm{a}}$ & $1.24^{\mathrm{c}}$ & $0.60^{\mathrm{b}}$ & $27.00^{\mathrm{b}}$ & $10.00^{\mathrm{b}}$ & 1.00 \\
\hline $10 / 12 / 10$ & $100 \mathrm{t} \mathrm{ha}^{-1}$ & $1.17^{\mathrm{b}}$ & $0.10^{\mathrm{a}}$ & $2.03^{\mathrm{b}}$ & $0.84^{\mathrm{a}}$ & $52.00^{\mathrm{a}}$ & $12.00^{\mathrm{c}}$ & 1.00 \\
\hline & Signf. & $* *$ & ns & $* *$ & $* *$ & $* * *$ & $* * *$ & ns \\
\hline & Time & $* *$ & $*$ & $* * *$ & $*$ & $* *$ & $* *$ & $\mathrm{~ns}$ \\
\hline & Time $\times$ treatment & $* *$ & $* *$ & $* * *$ & $* *$ & $* *$ & ns & ns \\
\hline Tomato & $0 \mathrm{t} \mathrm{ha}^{-1}$ & $2.23^{\mathrm{a}}$ & $0.01^{\mathrm{a}}$ & $4.02^{\mathrm{b}}$ & $0.16^{\mathrm{a}}$ & $27.00^{\mathrm{a}}$ & $4.50^{\mathrm{a}}$ & $<\mathrm{DL}$ \\
\hline (fruits) & $50 \mathrm{tha}^{-1}$ & $1.65^{\mathrm{c}}$ & $0.02^{\mathrm{a}}$ & $4.73^{\mathrm{a}}$ & $0.18^{\mathrm{a}}$ & $19.00^{\mathrm{a}}$ & $6.50^{\mathrm{a}}$ & 0.30 \\
\hline $10 / 12 / 10$ & $100 \mathrm{t} \mathrm{ha}^{-1}$ & $1.79^{\mathrm{b}}$ & $0.02^{\mathrm{a}}$ & $4.76^{\mathrm{a}}$ & $0.18^{\mathrm{a}}$ & $24.00^{\mathrm{a}}$ & $6.00^{\mathrm{a}}$ & 0.60 \\
\hline & Signf. & $* *$ & ns & $*$ & ns & $\mathrm{ns}$ & ns & ns \\
\hline Lettus & $0 \mathrm{t} \mathrm{ha}^{-1}$ & $2.33^{\mathrm{a}}$ & $0.21^{\mathrm{a}}$ & $3.50^{\mathrm{c}}$ & $0.37^{\mathrm{a}}$ & $20.00^{\mathrm{c}}$ & $10.00^{\mathrm{a}}$ & $2.60^{\mathrm{b}}$ \\
\hline ( $1^{\text {st }}$ harvest) & $50 \mathrm{t} \mathrm{ha}^{-1}$ & $2.06^{\mathrm{b}}$ & $0.13^{\mathrm{b}}$ & $5.50^{\mathrm{b}}$ & $0.25^{\mathrm{b}}$ & $40.00^{\mathrm{b}}$ & $11.00^{\mathrm{a}}$ & $6.80^{\mathrm{a}}$ \\
\hline $11 / 10 / 10$ & $100 \mathrm{t} \mathrm{ha}^{-1}$ & $2.44^{\mathrm{a}}$ & $0.13^{\mathrm{b}}$ & $6.71^{\mathrm{a}}$ & $0.28^{\mathrm{b}}$ & $76.00^{\mathrm{a}}$ & $11.00^{\mathrm{a}}$ & $3.90^{\mathrm{b}}$ \\
\hline & Signf. & $* *$ & $* *$ & $* * *$ & $* *$ & $* * *$ & $\mathrm{~ns}$ & $*$ \\
\hline Lettus & $0 \mathrm{t} \mathrm{ha}^{-1}$ & $4.22^{\mathrm{a}}$ & $0.12^{\mathrm{a}}$ & $3.01^{\mathrm{b}}$ & $0.25^{\mathrm{a}}$ & $27.00 \mathrm{~b}$ & $2.00^{\mathrm{b}}$ & $0.52^{\mathrm{a}}$ \\
\hline ( $2^{\text {nd }}$ harvest) & $50 \mathrm{tha}^{-1}$ & $1.62^{\mathrm{c}}$ & $0.12 \mathrm{a}$ & $4.52^{\mathrm{a}}$ & $0.23^{\mathrm{a}}$ & $32.00^{\mathrm{b}}$ & $3.00^{\mathrm{b}}$ & $0.82^{\mathrm{a}}$ \\
\hline $01 / 12 / 10$ & $100 \mathrm{tha}^{-1}$ & $2.03^{\mathrm{b}}$ & $0.12^{\mathrm{a}}$ & $5.17^{\mathrm{a}}$ & $0.22^{\mathrm{a}}$ & $44.00^{\mathrm{a}}$ & $6.20^{\mathrm{a}}$ & $0.34^{\mathrm{a}}$ \\
\hline & Signf. & $* * *$ & ns & $* * *$ & ns & $* *$ & $* *$ & ns \\
\hline & Time & $*$ & ns & $* * *$ & $*$ & $* *$ & $* *$ & $\mathrm{~ns}$ \\
\hline & Time $\times$ treatment & $* *$ & $*$ & $* * *$ & $*$ & $* *$ & ns & ns \\
\hline
\end{tabular}

${ }^{\dagger}$ Adapted from Giannakisa et al. (2014); TKN - total Kjedahl nitrogen; < DL represents detection limits, ns is non-significant at $5 \%$ probability level, $*_{p}<0.05, * * p<0.01, * * * p<0.001 ;$ abc represents values on the same column that are significantly different at 5,1 or $0.1 \%$ probability levels.

Suggestions for Reducing Some of the Problems Due to Land Application of Urban Refuse Wastes

- Untreated URWs should not be top dressed but immediately incorporated in to the soil.

- There is the urgent need for a comprehensive legal framework that facilitates enforcement of the existing regulations by the relevant authorities.

- The Federal and State environmental protection agencies currently charged with the statutory responsibility of enforcing regulations on waste management in Nigeria should be strengthened to ensure that each waste generating institution monitors its waste for presence of contaminants and reduce the volume of waste it generates.

- Government should prioritize composting of URW as a strategy for sustainable management of organic wastes rather than disposing in the landfill or dumpsite. This is because composting of biodegradable solid waste will result in generation of green manure which can be used for crop production.

- Those wastes that pose greater risk to public health should be properly land-filled or incinerated so as to avoid possible contamination of the ecosystem.
- Careful sorting of the wastes before it gets to the dump site or collection point offer a means of reducing possible contamination by hazardous wastes generated by industries, laboratories and health institutions across the country.

- Whenever URWs are recycled on a continuous basis, soil pH should be constantly monitored, as either too low or too high soil $\mathrm{pH}$ level can mobilize toxic metals thus increasing the risk of groundwater contamination especially on coarse textured soil with high infiltration rates.

- Because pathogen and heavy metal density of the URW are in most cases unknown, constant monitoring for presence of possible contaminants should be carried out whenever recycling of town refuse wastes is contemplated.

- Possible buildup of pathogens and heavy metals could be avoided by adopting application rates based on scientific principles of ecological sustainability.

- Potential health risks associated with pathogenic macro-organisms can be eliminated or reduced to barest minimum by composting the refuse wastes. 
- To prevent ground water contamination, excessive additions of untreated town refuse wastes should be avoided on excessively drained soil and/or sites with shallow and varying water tables. On such soils, a low application rate that takes into account previous additions and contaminants from other sources including nutrients should be considered.

- Government should promote academic research and industry linkages to fast-track generation of innovative technologies for sustainable management of solid wastes generated in the country.

- There is a need for massive campaign on attitudinal change towards improving the management of generated solid waste in the country.

- Households can have a significant impact toward sustainable solid waste management in urban areas once they are being involved in planning of solid waste management services.

- Government should strengthen extension service delivery for the purpose of mass sensitization of stakeholders notably policy makers to appreciate the need for establishing sustainable ways of managing solid waste in their respective localities.

- Extension workers should partner researchers to proffer innovative and participatory approach to public enlightenment of the rural dwellers on the importance of sustainable environment.

\section{Composting}

One proven option for solving many of the problems associated with direct soil application of raw or untreated URW is composting, defined as the biological decomposition or breakdown of organic wastes materials by mixed population of microorganisms in a warm, moist, aerated environment (Asomani-Boateng and Haight, 1999). This process eliminates or reduces any potential health risks to farmers and consumers that stem from the presence of pathogenic macro-organisms associated with reusing raw organic waste in urban cultivation. Once the organic fractions of the URW are composted, they cease to be the environment's principal contaminant. Soil application of URW compost (URWC) can play a vital role in the development and maintenance of soil organic matter content (Parr and Hornick, 1992), and at the same time may decrease the amount of water and fertilizer applied to crops (Ozares-Hampton et al., 1994; Ugwu et al., 2020). According to the findings of a study carried out in Tanzania, composting and bio fuels generation can convert up to $70 \%$ of the biodegradable waste such as food and garden wastes into useful products thereby saving landfill space needed to dispose biodegradable waste (Mombo and Bigirwa, 2017). However, in spite of the enormous potential for using URWC in growing crops (Ozares-Hampton and Bryan, 1993; OzaresHampton et al., 1994; Soumare et al., 2003), concerted efforts by governments and the private sector to encourage its use in agriculture is limited. Of much concern is the paucity of research data showing its potential for use as a soil amendment.
There is therefore an urgent need for research intervention to popularize the potential of the URW especially among urban farmers. Once this is done, it will be easier for the governments to enlist the support of important actors in the waste management planning process. It may be better to begin with community-based and simple composting techniques because experiences from other African countries have shown that the centralized and highly mechanized approaches to composting organic wastes have failed due mainly to constant mechanical failure, equipment that is expensive to procure, operate, and maintain; lack of technical knowledge to operate sophisticated equipment and processes; and the production of low quality, expensive compost (Asomani-Boateng and Haight, 1999). It is, however, important to note that though the community-based small-scale composting projects have shown some promise in many African countries (Mohee, 2007), such projects are often beset with problems that include: the difficulty of convincing households to source-separate their waste; negative attitudes of waste management officials to the idea of community composting; the lack of space for composting household waste, especially in poor and highdensity residential neighborhoods; and residents' lack of knowledge about the art of composting (Asomani-Boateng et al., 1996). The presence of large quantities of inert and non-biodegradable materials, such as plastics, glasses and metals in URWs, has been shown to reduce their value as organic fertilizers (Murillo et al., 1995). Strategies for addressing some of the challenges of low adoption of composting by households from developing countries include scaling up promotional campaigns on composting and developing innovative strategies for interested land-constrained urban dwellers (Nsimbe et al., 2018; Ugwu et al., 2020).

\section{Building Soil Organic Matter for Sustained Agricultural Productivity}

Protection and conservation of soil quality remains a major challenge particularly when dealing with fragile and sensitive ecosystems such as those of the arid and semi-arid West Africa. Environmental changes and anthropogenic impacts are potential threats to the conservation of soil quality in such ecosystems (Albaladejo et al., 1998). However, a key to restoration of these and similar ecosystems is to maximize the retention and recycling of soil organic matter and plant nutrients, and to minimize their losses caused by leaching, runoff and erosion (Bot and Benites, 2005; Obalum et al., 2017). Building soil organic matter through recycling of urban organic waste provides the means for enhancing soil health and allows sustained agricultural productivity. The improvement and maintenance of soil carbon and soil structure is necessary for sustainable agricultural systems and protection of the soil resource (Blair, 2000). 
The addition of organic solid wastes with high organic matter content to agricultural fields is a well-known practice for building soil organic matter. The amount of organic matter added to the soil will depend on the source, quality and the application rate of the wastes stream. Although town refuse wastes can be applied directly to farmland, it is advisable to apply it as biologically stable, screened finished compost for maximum benefits. Solid waste recovery alternatives such as composting have a great potential to turn waste into values thereby increasing the economic value of wastes, saving landfill space needed to dispose solid waste, encourage establishment of solid waste recovery industries or projects and create employment opportunities to people (Mombo and Bigirwa, 2017).

Mohee (2007) summarized the advantages of its application as compost as follows:

- All materials necessary for composting, such as feedstock, bulking agents, water, space, air and time are already on the farm.

- Disposal of raw manure such as poultry waste has a negative impact on the environment. Composting reduces the weight, moisture content, odour and vector attracting qualities of manure and other farm generated wastes leading to a lower risk of pollution.

- Compost can be applied at convenient times of the year because it provides the farmer with greater scheduling flexibility. While an untreated waste must be applied and incorporated promptly to prevent nitrogen loss and nuisance conditions, compost is stable and can be stored safely.

- Compost is an excellent soil conditioner. When applied to cropland compost adds organic matter improving moisture retention and soil structure, and reduces fertilizer requirements and the potential for soil erosion.

- Both compost and raw manure are good conditioners with some fertilizer value. Composting, however, converts the nitrogen contained in the manure into a more stable form. The nitrogen in compost is less susceptible to leaching and further ammonia losses.

- Highly bedded manure can have a high carbon to nitrogen $(\mathrm{C} / \mathrm{N})$ ratio. When applying this manure directly to land the high $\mathrm{C}$ causes the $\mathrm{N}$ in the soil to become unavailable to the crop. Composting reduces the $\mathrm{C} / \mathrm{N}$ ratio to levels that are beneficial to plants.

- Composting, if done properly, is an effective method of destroying pathogens. Properly prepared compost has been found to reduce soil borne plant diseases. The heat generated by the composting process reduces the number of weed seeds in the manure, resulting in a significant reduction of weeds over several years of application.

- The high cation exchange capacity (CEC) of compost leads to increased efficiency of chemical fertilizers by reducing nutrient leaching.

- Composting reduces the amount of on-farm organic waste for disposal, thus decreasing waste collection, transport and disposal costs.

- Compost is a safe and effective bedding material for livestock.
- Organic waste can generate an income by selling the compost. Good markets exist for high-quality compost and there are a many uses for lower grade compost.

- Composting is one of the few methods available for quickly creating a soil-like material on eroded land. Soil erosion has a direct financial impact on food production and the economy. Furthermore, eroded lands can lead to the pollution of surface water because of agricultural runoff from croplands.

Utilization of organic solid wastes as soil amendment remains a key factor in correcting many of the structural impediments associated with the soils of the sub-Saharan Africa. Investigating the impact of organic solid waste on physicochemical properties of Ferralsol in Owerri Nigeria, Okeke (2014) found that soils close to a refuse dumpsite showed higher values of organic carbon (1.90-3.20\%), total nitrogen (0.24-0.61\%) and available phosphorus (4.2-5.1 ppm) relative to the control sites. The findings also show that bulk density (1.2-1.5 $\mathrm{g} \mathrm{cm}^{-1}$ ) and $\mathrm{pH}$ (4.6-5.4) were lower in the dump sites than in the control.

Similar studies by Cercioglu et al. (2014) also showed that application of composted tobacco waste, chicken manure or bio-humus at 50, 4 and $10 \mathrm{tha}^{-1}$, respectively to a coarse-textured soil over a threeyear period had a positive impact on its physical characteristics because of their high organic matter content which promoted flocculation and aggregation of soil particles. Furthermore, bulk density decreased by $16.5 \%$, and porosity, field capacity, wilting point, available water content and structure stability index increased by $15.4,19.5,20.6,22.6$ and $26.8 \%$, respectively, as averaged across the three years and compared to the control plots. On coarse-textured soils as those mostly found in sub-Saharan Africa, the increase in aggregation associated with additions of organic solid wastes promote water infiltration (Ezenne et al., 2019), thereby reducing runoff and the likelihood of associated soil loss. Generally, the degree of surface soil aggregation will determine how tightly the soil particles are held during rain or wind storms (Obalum et al., 2019). Stable soil aggregates resist movement by wind or water because they are larger than primary particles of silt or clay.

Sustainability of Solid Waste Management in Nigeria Sustainable management of solid waste is a major challenge faced by municipal authorities in most countries across the sub-Saharan Africa. In Nigeria, for example, municipal authorities hardly cope with the huge quantities of wastes that are generated daily contaminating soil and water bodies thereby raising concerns for human health and environmental safety (Orhorhoro and Oghoghorie, 2019). Although many studies show that composting the large quantities of waste has the potential for creating a classical win-win situation by increasing urban and periurban agricultural production through appropriate soil fertility management, protecting the environment and enhanced income and livelihood generation 
(Drechsel and Kunze, 2001) concerns are expressed in some quarters regarding the sustainability of the practice in many countries of sub-Saharan Africa. An analysis of composting projects in West Africa suggests that apart from being too expensive, a common problem leading to project failure is poor co-ordination among institutions and stakeholders due to weak institutional linkages and the lack of an enabling institutional framework, including clear legislation and policies (Cofie et al., 2006). Other challenges identified include; lack of thorough market analysis including consideration of alternative soil inputs, transport costs, user's demand as well as willingness and ability to pay for compost prior to station set up, lack of financial viability of projects and supportive legal frameworks and institutional arrangement to implement composting initiatives.

However, a holistic approach that seeks to address many of the challenges highlighted above is necessary in order to guarantee a wellfunctioning composting system. One such approach is the nutrient recycling loop concept proposed earlier by Drechsel et al. (2002). The model provides a diagrammatic illustration of the systematic processes that are involved in composting - from waste generation, recycling to re-use as well as selecting an appropriate organic waste recycling technology at the appropriate scale of intervention. The various segments of the model include: urban consumption and waste generation, waste processing, compost demand for agriculture, along with an economic feedback mechanism and finally the legal, institutional and communal settings throughout the loop (Cofie et al., 2006).

The proposed model looks at the urban consumption and waste generation; waste processing; compost demand; and as well as the legal, institutional and communal settings, in which the issues of planning, regulations, by-laws, policy constraints or support, land availability, local stakeholder participation, monitoring and evaluation, inter/intra-sectoral corporations, etc. are holistically addressed, throughout the cycle of analysis. The nutrient recycling loop has been found to be useful in assessing all the processes involved in recycling organic waste into a valuable resource at municipal (centralized), community (decentralized) and/or household (backyard) levels for use in urban agriculture. In view of the above, any strategy for improving URWs management in Nigeria has to focus on the following initiatives; institutional reform, technology development and legislative and administrative improvement. Addressing some of the aforementioned constraints associated with the re-use of organic wastes will undoubtedly encourage the sustainable exploitation of URW by the urban and peri-urban farmers many of whom have already realized many of the potential benefits of composting. Because of the high levels of organic matter within the region's waste streams, diverting this waste into resource recovery systems presents a sizeable untapped potential for extending the life of landfills, creating economic and environmental benefits, and ultimately reducing the pressure on municipalities to manage the everincreasing complexity of waste systems.

\section{CONCLUSION}

The various studies reviewed here have shown that utilizing urban refuse wastes (URWs) on cropland is one of the possible solutions for the complex problem of waste disposal in most municipal authorities. Therefore, if properly managed and utilized, urban refuse could provide means of improving many of the soil productivity constraints in the West African sub-region in particular and similar regions of the world. The quality of URWs intended for use as bio-fertilizers could be improved through sorting and composting of their organic fraction. If, however, the benefits of composting urban organic wastes can be demonstrated to the farming communities, it is easy to get the governments involved, since their rapid accumulation from rural urban centers constitutes a serious environmental hazard. Research efforts should be directed towards assessment of potential risk of contamination of surface and underground waters through leaching of nutrients from added URWs.

ACKNOWLEDGEMENTS We thank colleagues in the Department of Soil Science, University of Maiduguri for their valuable comments on the manuscript.

\section{REFERENCES}

Abdel Magid H.M., Sabrah R.E.A., El-Nadi A.R.H., Abdel Aal S.I. and Rabie R.K. (1994). Kinetics of biodegradation rates of chicken manure and municipal refuse in a sandy soil. J. Arid Environ., 28, 163-171

Adedibu A.A. and Okenkule A.A. (1989). Issues on the environmental sanitation of Lagos mainland Nigeria. Environmentalist, 9, 91-100

Adubasim C.V., Igwenagu C.M., Josiah G.O., et al. (2018). Substitution of manure source and aerator in nursery media on sandy-loam topsoil and their fertility indices 4 months after formulation. Int. $J$. Recycling Organic Waste Agric, 7 (4), 305-312. DOI: $10.1007 / \mathrm{s} 40093-018-0216-8$

Ajadi B.S. and Tunde A.M. (2010). Spatial variation in solid waste composition and management in Ilorin metropolis Nigeria. J. Hum. Ecol., 32, 101-108

Akintola O.A., Idowu O.O., Lateef S.A., et al. (2019). The use of waste management techniques to enhance household income and reduce urban water pollution. p. 16. Accessed $18^{\text {th }}$ June 2020 from: $\mathrm{http} / /$ creativecommons.org/ licenses/by/3.0

Albaladejo J., Martinez-Mena M., Roldan A. and Castillo V. (1998). Soil degradation and desertification induced by vegetation removal in a semi arid environment. Soil Use Manage., 14, 1-5

Alloway B.J. (1996). Heavy Metal in Soil (pp.). Halsted Press, John Wiley \& Sons Inc., London, pp. 230-239 
Amhakhian S.O., Ezeaku P.I. and Olimah J.A. (2003). Effects of heavy metal on amaranthus grown on a municipal waste disposal site at Anyigba Kogi State Nigeria. Proc. 28 th Ann. Conf. Soil Sci. Soc. Nig., pp. 208-211

Amusan A.A., Ige D.V. and Olawale R. (2005). Characteristics of soils and crops uptake of metals in municipal waste dump sites in Nigeria. J. Hum. Ecol., 17, 167-171

Anyanwu N.C. and Adefila J.O. (2014). Nature and management of solid waste in Karu Nasarawa State Nigeria. Amer. Int. J. Contemp. Res., 4, 149-159

Asomani-Boateng R. and Murray H. (1999). Reusing organic solid waste in urban farming in African cities: A challenge for urban planners. Int. Dev. Res. Centre, Ottawa Canada \& Tech. Centre Agric. Rural Coop. $A C P-E U$, Wageningen, Netherlands, pp. 138-154

Asomani-Boateng R., Haight M. and Furedy C. (1996). From dump to heap: Community composting in West Africa. Biocycle, 37 (1), 70-71

Bababe B. and Kwari J.D. (1999). Appraisal of farmers' initiative in the use of soil organic amendment in the Sudano-Sahelian region of Northeastern Nigeria. In: R.G. Krieg, S.P. Lawrence, M. von Oppen (eds.), Farmers and Scientists in a Changing Environment: Assessing Research in West Africa (pp. 87-97). Margraf Varlag Weikersheim, Germany

Baiyeri P.K., Ugese F.D., Obalum S.E. and Nwobodo C.E. (2020). Agricultural waste management for horticulture revolution in sub-Saharan Africa. CAB Int., 15 (17). Available at: http://www.cabi.org/cabreviews

Bazzoffi P., Pellegrini S., Rocchini A., Morandi M. and Grasselli O. (1998). The effect of urban refuse compost and different tractor tyres on soil physical properties, soil erosion and maize yield. Soil Till. Res., 48, 275-286

Bhattacharyya P., Chakraborty A., Bhattacharya B. and Chakrabarti K. (2003). Evaluation of MSW compost as a component of integrated nutrient management in wetland rice. Compost Sci. Util., 11, 343-350. DOI: 10.1080/1065657X.2003.10702144

Blair N. (2000). Impact of cultivation and sugar-cane green trash management on carbon fractions and aggregate stability for a chromic Luvisol in Queensland, Australia. Soil Till. Res., 55, 183-191

Bot A. and Benites J. (2005). The importance of soil organic matter: Key to drought-resistant soil and sustained food and production. FAO Soil Bull., 80, 78

Bununu A.M., Adamu S. and Mohammed G.U. (2011). Physico-chemical characteristics of municipal solid waste in Bauchi metropolis, Bauchi State. J. Environ. Technol. Sustain. Agric., 2, 148-155

Butu A.W. and Mshelia S.S. (2014). Municipal solid waste disposal and environmental issues in Kano metropolis, Nigeria. Brit. J. Environ. Sci., 2, 10-26

Cercioglu M., Okur B., Delibacak S. and Ongun A.R. (2014). Changes in physical conditions of a coarse textured soil by addition of organic wastes. Eurasian J. Soil Sci., 3, 7-12

Chong C. (2001). Growing on wastes: A success story and resource. Proceedings of the National Strategic Planning Workshop on Floriculture and Ornamental Horticulture Research, August, Toronto, pp. 23-24

Cofie O., Adam-Bradford A. and Drechsel P. (2006). Recycling of urban organic waste for urban agriculture. Accessed 18 $8^{\text {th }}$ June 2020 from: http:// www.urbanagricultureeurope.la.rwth-aachen.de/files/

Cristina M.A. (2013). Glance at the world. Waste Manage., 33, 251-254
Cullen A.C. (1995). The sensitivity of probabilistic risk assessment results to alternative model structure: A case study of municipal waste incineration. J. Air Waste Manag. Assoc., 45, 538-546

Debiase G., Montemurro F., Fiore A., et al. (2016). Organic amendment and minimum tillage in winter wheat grown in Mediterranean conditions: Effects on yield performance, soil fertility and environmental impact. Europ. J. Agron., 75, 149-157

Drechsel P. and Kunze D. (2001). Waste composting for urban and peri-urban agriculture: closing the rural-urban nutrient cycle in sub-Saharan Africa. International Water Management Institute, FAO \& CABI Publ, Wallingford, UK, $229 \mathrm{pp}$.

Drechsel P., Danso G. and Keraita B. (2002). Soil nutrient depletion vs. environmental pollution: The dilemma of intensive urban agriculture. Paper for ISCO 2002, Beijing, 26-31 May, 2002

El-Nadi A.R.H., Rabie R.K., Abdel Magid H.M., Sabrah R.E.A. and Abdel Aal S.I. (1995). Chemical, physical and microbiological examination of town refuse compost and chicken manure as organic fertilizers. $J$. Arid Environ., 30, 107-113

Ezenne G.I., Obalum S.E. and Tanner J. (2019). Physicalhydraulic properties of tropical sandy-loam soil in response to rice-husk dust and cattle dung amendments and surface mulching. Hydrol. Sci. J., 64 (14), 1746-1754. https://doi.org/10.1080/0262 6667.2019.1662909

Fajemisin J.M. (1991). Approaches to increased production of early-maturing maize in semi-arid West Africa. Proc. Int. Conf. Influence of the Climate on the Production of Tropical Crops (pp. 23-28), Burkina Faso

Federal Ministry of Housing and Environment (1982). The State of the Environment in Nigeria.

Felton G.K. (1995). Temporal variation of soil hydraulic properties on urban refuse amended mine soils. Trans. ASAE, 38, 775-782

Ghaly A.E. and Alkonik F.N. (2010). Effect of municipal solid waste compost on the growth and production of vegetable crops. Am. J. Agric. Biol. Sci., 5, 274-281

Giannakisa G.V., Kourgialasa N.N., Paranychianakisa N.V., Nikolaidisa N.P. and Kalogerakisa N. (2014). Effects of municipal solid waste compost on soil properties and vegetables growth. Compost Sci. Util., 22, 116-131

Harir A.I., Kashim R. and Ishiyaku B. (2015). Exploring the resource recovery potentials of municipal solid waste: A review of solid wastes composting in developing countries. Int. J. Sci. Res. Pub., 5, 2250-3153

Hoornweg D., Thomas L. and Otten L. (2014). Composting and its application in developing countries. Urban Waste Management Working Paper 8, Urban Development Division, World Bank. Washington DC

Hossain M.Z., Niemsdorff P.F. and Heß J. (2017). Effect of different organic wastes on soil properties and plant growth and yield: A review. Sci. Agric. Biochem., 48 (4), 224-237

Karl M., Samann M. and Johances K. (1994). Sustaining Growth: Soil Fertility Management in Tropical SmallHoldings. Margraf Verlag, Weikersheim, Germany, $486 \mathrm{pp}$.

Khaleel R., Reddy K.R. and Ovgercash M.R. (1981). Changes in soil physical properties due to organic waste application: A review. J. Environ. Qual., 10, 133-141

Lapworth D.J., Stuart M.E., Pedley S., Nkhuwa D.C.W. and Tijani M.N. (2018). A review of urban groundwater use and water quality challenges in sub-Saharan Africa. British Geological Survey Ground Water Programme Open Report OR/17/056 
Lewcock C.P. (1995). Farmer's use of urban waste in Kano. Habit. Int., 19, 225-234

Madeleine I., de-Smet P., Tim T. and Tom V. (1990). The Preparation and Use of Compost (p. 12). Agrodok Agromisa, Wageningen, Netherlands

Maton S.M., Dabi D.D., Dodo J.D. and Nesla R.A. (2016). Environmental hazards of continued solid waste generation and poor disposal in municipal areas of Nigeria. J. Geo. Environ. Earth Sci. Int., 6 (3), 1-10

Mohee R. (2007). Waste management opportunities for rural communities: composting as an effective waste management strategy for farm households and others. Agric. Food Eng. Wkg. Doc. No. 6. FAO, UN, Rome

Mombo F. and Bigirwa D. (2017). The role of sub-Saharan African countries' households waste charges on sustainable cities development. Int. J. Waste Resour., 7 (1), 1-6

Mortimore M.J. (1972). Some aspects of rural-urban relations in Kano, Nigeria. In: Vennetier P. (ed.), La Croissance Urbaine en Afrique Noire et Madagascar (pp. 871-88). Colloques Internationaux du CNRS 539, Centre National de la Recherche Scientifique, Paris

Murillo J.M., Lopez R., Cabreram F. and Olmeda M. (1995). Testing a low quality urban compost as a fertilizer for arable farming. Soil Use Manag., 11, 127-131

Nicou R. and Charreau C. (1985). Soil tillage and water conservation in semi-arid West Africa. In: Ohm H.W. and Nagy J.G. (eds.), Appropriate Technologies for Farmers in Semi-arid West Africa (pp. 9-32). Proc. Workshop Purdue University, West Lafayatte

Njoku C. (2015). Effect of wastes on selected soil properties in Abakaliki Southeastern Nigeria. Int. J. Plant Soil Sci., 4 (1), 94-99

Nsimbe P., Mendoza H., Wafula S.T. and Ndejjo R. (2018). Factors associated with composting of solid waste at household level in Masaka municipality, Central Uganda. J. Environ. Public Health, ID 1284234, 7

Obalum S.E., Chibuike G.U., Peth S. and Ouyang Y. (2017). Soil organic matter as sole indicator of soil degradation. Environ. Monitoring Assessment, 189 (4), Article 176. DOI: 10.1007/s10661-017-5881-y

Obalum S.E., Uteau-Puschmann D. and Peth S. (2019). Reduced tillage and compost effects on soil aggregate stability of a silt-loam Luvisol using different aggregate stability tests. Soil Till. Res., 189 (1-2), 217-228. https://doi.org/10.1016/j.still.2019.02.002

Ogwueleka T.C. (2009). Municipal solid waste characteristics and management in Nigeria. Iranian $J$. Environ. Health Sci. Eng., 6 (3), 173-180

Okeke P.N. (2014). Impact of solid waste on physicochemical properties of Ferrealsol in Owerri Nigeria. Afr. Res. Rev., 8, 116-122

Olayiwola H.A., Abudulawal L., Adewuyi G.K. and Azeez M.O. (2017). Heavy metal contents in soil and plants at dumpsites: A case Study of Awotan and Ajakanga dumpsite Ibadan, Oyo State Nigeria. $J$. Environ. Earth Sci., 7 (4), 11-24

Onibokun A.G. (1989). Urban growth and management in Nigeria. In: R.E. Stren and White R.R. (eds.), African Cities in Crisis: Managing Rapid Urban Growth (pp. 69-111). West View Press, Boulder, CO, USA

Onwudiwe N., Benedict O.U., Ogbonna P.E. and Ejiofor E.E. (2014). Municipal solid waste and NPK fertilizer effects on soil physical properties and maize performance in Nsukka, Southeast Nigeria. Afr. J. Biotechnol., 13, 68-75
Orhorhoro E.K. and Oghoghorie O. (2019). Review on solid waste generation and management in subSaharan Africa: A case study of Nigeria. J. Appl. Sci. Environ. Manage., 23 (9), 1729-1737

Ouni Y., Albacete A., Cantero E., et al. (2014). Influence of municipal solid waste (MSW) compost on hormonal status and biomass partitioning in two forage species growing under saline soil conditions. Ecol. Eng., 64, 142-150

Oyelola O. and Babatunde A.I. (2008). Effect of municipal solid waste on the levels of heavy metals in Olusosun dumpsite soil, Lagos State Nigeria. Int. J. Pure Appl. Sci., 2(1), 17-21

Ozares-Hampton M. and Bryan H.H. (1993). Effect of amending soil with municipal solid waste (MSW) compost on yield of bell peppers and eggplant. Hort. Sci., 28, 103-115

Ozares-Hampton M., Schaffer B. and Bryan H.H. (1994). Influence of municipal solid waste (MSW) compost on growth, yield and heavy metal content of tomato. Hort. Sci., 38, 162-167

Papafilippaki A., Paranychianakis N. and Nikolaidis N.P. (2015). Effects of soil type and municipal solid waste compost as soil amendment on Cichorium spinosum (spiny chicory) growth. Sci. Hort., 195, 195-205

Parr J.F. and Hornick S.B. (1992). Utilization of municipal wastes. In: Metting B. (ed.), Soil Microbial Ecology: Application in Agriculture, Forestry and Environ-mental Management (pp. 545-559). Marcel Dekker, New York

Pieri C. and Steiner K.G. (1997). The role of soil fertility in sustainable agriculture with special reference to sub-saharan Africa. Agric. Rural Dev., 4, 22-25

Pierzynski G.M. and Gehl K.A. (2005). Plant nutrient issues for sustainable land application. J. Environ. Qual., 34, 18-28

Ros M., Garcia C. and Hernandex T. (2001). The use of urban organic wastes in the control of erosion in a semi-arid Meditteranean soil. Soil Use Manag., 17, 292-298

Scotti R., Pane C., Spaccini R., et al. (2016). On-farm compost: A useful tool to improve soil quality under intensive farming systems. Appl. Soil Ecol., 107, 13-23

Soumare M., Tack F.M. and Verloo M.G. (2003). Effects of a municipal solid compost and mineral fertiliza tion on plant growth in two tropical agricultural soils of Mali. Bioresour. Technol., 86, 15-20

Stevens C.G., Ugese F.D. and Baiyeri K.P. (2018). Effect of pig manure on growth and productivity of twenty accessions of Moringa oleifera in Nigeria. AgroScience, 17 (3), 19-26. DOI: 10.4314/as.v17i3.4

Taddese S. (2019). Municipal waste disposal on soil quality: A review. Acta Sci. Agric., 3 (12), 9-15

Ubuoh E.A., Akhionbare W.N., Akhionbare S.M.O., Akande S.O. and Ikhile C. (2012). The potentials of solid wastes utilization for agriculture in Imo State, Nigeria. Int. J. Multidiscipl. Sci. Eng., 3, 42-45

Ugwu V.U., Nnadi A.L., Adubasim C.V., et al. (2020). Organic-waste aerator could completely displace poultry-droppings manure in nursery media based on coarse-textured soil: evidence with cashew seedlings. In: Baiyeri K.P. and Aba S.C. (eds.), Sustainable Horticulture Production System Intensified (pp. 941-951), Proc. 38th Annual Conf. Hort. Soc. Nigeria (HORTSON), University of Nigeria Nsukka, 25-31 Oct. 2020 